\title{
Kloning Manusia Perspektif Hukum Islam Di Indonesia*
}

\author{
(Human cloning in islamic law perspective In indonesia)
}

\author{
La Jamaa \\ Fakultas Syariah dan Ekonomi Islam IAIN Ambon \\ Jl. Dr. H. Tarmizi Tahir Kebun Cengkeh Batu Merah Atas Ambon \\ Email: lajamaa26@gmail.com
}

\begin{abstract}
doi $\underline{10.15408 / \text { sjsbs.v3i1.3163 }}$
Abstract:

Reproductive cloning technology is able to facilitate artificial fertilization by using the husband's body and wife's ovum, as well the embryo transferred to the womb of the wife. So that, human cloning can give benefit to husband and wife to get child. However, human cloning technology has negative implications in case of marriage, jurisprudence, guardianship, inheritance, and investigation of criminal offense, because a person may have children cloned without marital status that can underestimate the institution of marriage. The "Nasab" of cloned child is also unclear, so it affects the guardianship, inheritance, father's responsibility to the child. Therefore, Islamic law in Indonesia prohibits human cloning.

Keywords: Human Cloning, Islamic Law, Marriage.
\end{abstract}

\begin{abstract}
Abstrak.
Teknologi kloning reproduksi mampu memfasilitasi pembuahan buatan dengan menggunakan sel tubuh suami dan ovum istri, serta embrionya ditransfer ke rahim istri. Sehingga kloning manusia dapat memberikan kemaslahatan terhadap pasangan suami istri yang tidak subur untuk memperoleh keturunan. Namun demikian, teknologi kloning manusia berimplikasi negatif, baik terhadap institusi perkawinan, nasab, perwalian, kewarisan, serta penyelidikan dan penyidikan pelaku tindak pidana. Sebab seseorang bisa punya anak secara kloning tanpa ikatan perkawinan sehingga bisa menyepelekan institusi perkawinan. Nasab anak hasil kloning juga tidak jelas sehingga berpengaruh pada perwalian, kewarisan, tanggungjawab ayah kepada anak dan sebaliknya. Karena itu hukum Islam di Indonesia melarang kloning manusia.
\end{abstract}

Kata Kunci: Kloning Manusia, Hukum Islam, Perkawinan.

* Diterima tanggal naskah diterima: 9 Februari 2016, direvisi: 11 Maret 2016, disetujui untuk terbit: 12 April 2016. 


\section{Pendahuluan}

Perkawinan menjadi sebuah insitutisi yang melegalkan hubungan seorang laki-laki dengan seorang perempuan untuk membangun rumah tangga yang bahagia. Perkawinan pada hakekatnya bertujuan untuk mewujudkan kebahagiaan rumah tangga. Kebahagiaan rumah tangga yang dibangun suami istri seringkali menjadi terganggu lantaran keterlambatan hadirnya anak dalam kehidupan mereka. Dalam kaitan ini, bagi pasangan suami istri yang berpikir positif atau berjiwa besar tidak akan mempermasalahkannya, namun bagi sebagian pasangan suami istri menganggap kebahagiaan rumah tangganya tak sempurna tanpa ada anak yang lahir dari rahim istri sendiri. Kegelisahan suami dalam merespon kondisi itu dapat mendorongnya menikah lagi secara poligami dengan harapan bisa memperoleh keturunan dengan istrinya yang baru. Bahkan ada pasangan suami istri lebih memilih solusi melalui perceraian. Dengan demikian kegagalan memperoleh anak dalam sebuah perkawinan dapat menghancurkan perkawinan.

Mencermati fenomena tersebut sepanjang sejarah umat manusia, para ilmuan telah melakukan eksperimen yang dapat menjadi solusi terhadap kesulitan mendapatkan anak melalui kehamilan alami, yaitu teknologi bayi tabung. Kehadiran teknologi bayi tabung menjembatani harapan pasangan suami istri untuk memperoleh keturunan (anak kandung) dalam menghadapi realitas kesulitan kehamilan alami pada istrinya. Teknologi bayi tabung menjadi alternatif yang tepat dengan syarat suami istri memiliki sperma dan ovum yang subur. Dengan demikian teknologi bayi tabung tak dapat digunakan untuk pasangan suami istri yang salah seorang atau kedua-duanya tidak subur. Namun hal itu dapat diatasi dengan teknologi kloning. Melalui rekayasa genetika dengan memanfaatkan kode-kode Deoxyribon Neuclied Acid (DNA), reproduksi manusia dapat dilakukan dengan tanpa memfungsikan sel-sel kelamin. Jadi, kloning merupakan teknik reproduksi makhluk hidup secara aseksual, sehingga dalam teknologi kloning sel-sel kelamin tidak berperan dalam reproduksi manusia.

Eksperiman reproduksi melalui kloning menggunakan sampel penelitian berupa kodok. Eksperimen tersebut dilakukan oleh Robert Briggs dan Thomas King tahun 1952; dan tahun 1996, Ian Wilmut berhasil mengkloning domba dari inti sel epitel kelenjar susu domba Finn Dorzet (sebagai jantan) dengan sel telur yang telah dimandulkan dari domba Scottiah Blackface. Eksperimen itu sukses dilahirkan seekor domba kloning yang memiliki sifat-sifat yang identik dengan donornya (Finn Dorset). ${ }^{1}$ Dengan demikian dapat diungkapkan bahwa sifat-sifat menurun yang diwarisi turunan (hasil kloning) hanya berasal dari pemilik inti sel tubuh, sedangkan sel telur (ovum) tidak memberikan kontribusi hereditas

${ }^{1}$ Lihat Tim Fakultas Teknik UMJ Jakarta, Islam dan IPTEK, Buku Kedua (Cet. 1; Jakarta: PT Raja Grafindo Persada, 1998), h. 166-167. 
(sifat-sifat menurun) sama sekali. Jelasnya, bahwa manifestasi dari gen pada keturunan (hasil kloning) akan memperlihatkan sifat-sifat yang identik dengan induknya (pemilik inti sel tubuh).

Berdasarkan perjalanan panjang penelitian tersebut, usaha melakukan kloning manusia akan semakin terbuka. Hal ini mirip dengan penelitian terhadap bayi tabung, yang pada awalnya diujicobakan pada tumbuhan dan hewan, tetapi akhirnya bayi tabung manusia telah menjadi kenyataan dalam kehidupan masyarakat modern. Dalam kaitannya dengan kloning manusia, secara genetika sifat-sifat menurun yang diwariskan kepada anak hanya berasal dari orang yang menjadi sumber inti sel tubuh (sel somatik) yang telah ditanamkan pada sel telur wanita, baik pemilik inti sel tubuh itu laki-laki mau pun wanita. ${ }^{2}$ Karena inti sel tersebut telah memiliki 46 kromosom. Sedangkan sel telur wanita yang dibuahi oleh inti sel itu sebenarnya telah kosong (tidak mempunyai kromosom lagi) sehingga tidak akan mewariskan sifat-sifat genetika kepada keturunannya.

Reproduksi manusia secara kloning dapat digunakan untuk mencetak manusia-manusia unggul, baik kecerdasan, kekuatan fisik, kesehatan, kecantikan (ketampanan) mau pun memperbanyak jumlah penduduk. Jelasnya, bahwa pada satu sisi kloning hewan dan tumbuhan memberikan manfaat bagi manusia namun pada sisi lain kloning manusia dapat menimbulkan problema bagi kemanusiaan (martabat manusia). Karena itu kloning manusia terasa urgen untuk dikaji implikasinya dalam hukum Islam di Indonesia, baik hukum Islam dalam fikih, Undang-Undang Perkawinan, Kompilasi Hukum Islam, maupun Fatwa Majelis Ulama Indonesia. Kajian ini bertitiktolak dari teori lingkaran konsentris dari Muhammad Tahir Azhary, bahwa ada hubungan yang erat antara agama, hukum dan negara, bahkan ketiga komponen tersebut berada dalam satu kesatuan yang tidak dipisahkan. ${ }^{3}$ Relevan dengan hal itu hukum Islam telah memberikan kontribusi dalam tatanan hukum nasional yang diwujudkan dalam berbagai produk hukum yang mengikat bagi umat Islam Indonesia.

\section{Pengertian Kloning}

Secara etimologi, istilah kloning sebenarnya berasal dari bahasa Yunani yaitu kata clon, yang berarti tangkai. Clon, adalah "suatu populasi sel atau organisme yang terbentuk melalui pembelahan yang berulang (aseksual) dari

${ }^{2}$ Lihat Barbara Letta Cole, et al., Encyclopedia Americana, Vol. 7 (Danbura: Grolier Incorporated, 1993), h. 97.

${ }^{3}$ Muhammad Tahir Azhary, Negara Hukum Suatu Studi tentang Prinsip-Prinsipnya Dilihat dari Segi Hukum Islam, Implementasinya pada Periode Negara Madinah dan Masa Kini (Edisi kedua, Cet. 2; Jakarta: Prenada media, 2004), h. 68. 
satu sel."4 Sedangkan kloning berasal dari bahasa Inggris, cloning adalah "suatu usaha untuk menciptakan duplikat suatu organisme melalui proses yang aseksual." ${ }^{5}$

Dengan kata lain, kloning adalah proses memperoleh keturunan (reproduksi) secara aseksual suatu sel tunggal. ${ }^{6}$ Sel tunggal yang dimaksudkan di sini adalah inti sel tubuh hewan dan manusia atau sel daun pada tumbuhan. Hasil kloning adalah klon, yaitu populasi yang berasal dari satu sel atau organisme yang mempunyai rangkaian kromosom yang sama dan sifat yang identik dengan induk asalnya. ${ }^{7}$ Kloning juga berarti "pembentukan dua individu/lebih yang identik secara genetik." 8 Dengan demikian, kloning merupakan teknik reproduksi secara aseksual dengan kode genetik yang sama dengan induknya pada makhluk hidup tertentu, baik berupa tumbuhan, hewan maupun manusia.

\section{Sejarah dan Proses Kloning}

Dalam uraian sebelumnya telah dikemukakan bahwa kloning merupakan hasil kemajuan dalam bioteknologi, yaitu "teknologi yang menyangkut jasad hidup." ${ }^{9}$ Dari bioteknologi melahirkan biotek, yaitu pemanfaatan sistem bioteknologi untuk menghasilkan barang dan jasa bagi kepentingan manusia. Jadi, bioteknologi adalah teknik penggunaan makhluk hidup atau bahan yang didapat dari makhluk hidup untuk membuat suatu produk yang bermanfaat bagi manusia, atau suatu proses dalam mengaplikasikan teknik-teknik (alat-alat) terhadap makhluk hidup untuk melakukan sesuatu yang diinginkan. ${ }^{10}$

Perkembangan bioteknologi melanda dunia ilmu pengetahuan, secara faktual dapat disaksikan pada tahun 1953 Watson dan Crick memenangkan Hadiah Nobel bidang biokimia atas keberhasilan penelitian mereka dalam menyingkap struktur kimia molekul DNA (deoxyribo Neucleid Acid) yaitu suatu

${ }^{4}$ Lihat Barbara Letta Cole, et al., Encyclopedia Americana, h. 97.

${ }^{5}$ Soetandyo Wignjosoebroto, "Kloning: Kemungkinan Teknis dan Implikasi Permasalahan Sosial-Etisnya," dalam Aziz Mushofa dan Imam Musbikin, Kloning Manusia Abad XXI: Antara Harapan, Tantangan dan Pertentangan (Cet. I; Yogyakarta: Forum Studi HIMANDA dan Pustaka Pelajar, 2001), h. 16.

${ }^{6}$ Munawar Ahmad Anees, Islam and Biological Futures: Ethics, Gender and Technology, terj. Rahmani Astuti, Masa Depan Biologis Umat Manusia: Etika Gender dan Teknologi (Cet. I; Bandung: Mizan, 1993), h. 13.

${ }^{7}$ Lihat Abdul Qadir Zullum, Kloning dan Permasalahannya (Bandung: Mizan, 1997), h. 10.

'Sulchan Sofoewan, "Perkembangan IPTEKDOK Dalam Rekayasa Reproduksi," dalam Muhammad Azhar dan Hamim Ilyas, Perkembangan Pemikiran Keislaman Muhammadiyah: Purifikasi dan Dinamisasi (Cet. I; Yogyakarta: LPPI UMY, 2000), h. 173.

9J.S. Badudu dan Sutan Muhammad Zain, Kamus Besar Bahasa Indonesia (Cet. I; Jakarta: Pustaka Sinar Harapan, 1994), h. 190.

${ }^{10}$ Lihat Tim Fakultas Teknik UMJ Jakarta, Islam dan IPTEK, h. 160. 
materi genetik yang bertanggung jawab dalam pemindahan sifat dari induk (orang tua) kepada keturunannya. ${ }^{11}$

Struktur kimia DNA terdiri dari dua untai asam nukleat yang komplementer, membentuk struktur terpilih, dikenal sebagai struktur a-double helix (untai ganda DNA). Di dalam struktur DNA itulah terdapat gen yakni segmen tertentu dari untaian DNA yang mempunyai fungsi melalui proses tertentu dalam metabolisme atau aktivitas makhluk hidup, baik hewan, tumbuhan mau pun manusia. ${ }^{12}$ Dengan demikian, DNA merupakan tempat penyimpanan semua informasi makhluk yang bersangkutan. Jika makhluk itu melakukan reproduksi, baik melalui aseksual (mikroorganisme) maupun seksual (hewan dan manusia), maka gen itu akan dipindahkan dari induk kepada keturunannya, dan manifestasi gen pada keturunannya akan memperlihatkan kesamaan sifat dengan induknya. Dengan diketahuinya struktur kimia DNA atau gen, maka manusia mulai mempunyai kemampuan untuk mengontrol kerja DNA itu.

Setelah kode-kode genetik pada segmen DNA mulai bisa "dibaca," para pakar biologi molekuler telah dapat "membaca" kode-kode pada struktur gen. Jelasnya dapat diketahui bahwa suatu gen dengan struktur tertentu akan menjadi proses tertentu pula. Tahun 1979 ditemukan enzim restriksi endonukleasesuatu enzim yang dapat digunakan untuk memotong DNA pada tempat-tempat yang dikehendaki- selain itu ditemukan pula enzim legase yang mampu menyambung kembali rangkaian DNA yang telah diiris oleh enzim restriksi endonuklease. ${ }^{13}$ Dengan kata lain, manusia telah dikaruniai kemampuan untuk mengiris DNA (gen) itu dengan lem DNA berupa enzim legase. Dengan temuan itu, para pakar biologi molekuler dapat melakukan pengirisan DNA pada segmen tertentu, memindahkan irisan DNA itu dan disambungkan ke DNA yang lain dari makhluk yang lain pula. Inilah yang disebut teknologi genetik atau teknik rekombinasi DNA.

Perkembangan yang dramatis terjadi pula pada tahun 1986 ketika Marry dari Cetus Corporation menekan polymerase Chain Reaction (PCR) atau reaksi berantai polimerase dengan menggunakan teknologi PCR, DNA (gen) dapat diperbanyak dalam jutaan kali DNA yang identik dalam waktu 24 jam. Dengan kata lain, dengan teknologi PCR, DNA (gen) bisa dicopy menjadi jutaan kali lipat DNA yang identik. ${ }^{14}$ Aplikasi bioteknologi dari biologi molekuler inilah yang dikenal denan bioteknologi modern. Melalui bioteknologi ini pula kloning, baik terhadap tumbuhan, hewan mau pun manusia, dapat dilakukan. Kloning pada

${ }^{11}$ Lihat M. Nurchalis Bakry, dkk., Bioteknologi dan Al-Qur'an (Cet. II; Jakarta: Gema Insani Press, 1996), h. 108.

${ }^{12}$ Lihat S.M. Issoegianti Reksoatmojo, Biologi Sel (Cet. I; Jakarta: Depdikbud, 1994), h. 114.

${ }^{13}$ Lihat Nurchalis Bakry, Bioteknologi dan Al-Qur'an, h. 62.

${ }^{14}$ Lihat Ika N. Krishnayanti, Bioteknologi dan Keselamatan Hayati, (Jakarta: Konpalindo, 1995), h. 45. 
tumbuhan dilakukan pada sel daun atau sel lainnya. Hal itu telah banyak dilakukan seperti karet, anggrek, pisang dan sebagainya.

Kloning pada hewan diujicobakan pada domba. Dalam prosesnya inti sel tubuh diambil dari kelenjar susu domba Finn Dorset, kemudian ditempatkan dalam cawan petri berisi nutrisi berkonsentrasi rendah. Karena kelaparan, maka sel berhenti membelah dan gen (sementara) tidak menjadi aktif. Sel telur yang telah dimandulkan diambil dari domba betina dari spesies Scottish Blackface. Inti sel (berikut DNA)nya dibuang sehingga menjadi sel telur yang kosong dan siap memproduksi menjadi embrio. Sebagai gantinya dimasukkan sel donor berisi DNA dari domba Finn Forget ke dalam cawan tabung reaksi.

Langkah berikutnya, dalam tabung itu kedua sel, dengan bantuan cairan kimiawi khusus dan rangsangan arus listrik, berdekatan satu sama lain dan bereaksi. Penggabungan terjadi dalam lingkungan energi yang cukup untuk pembelahan sel. Setelah 6 hari embrio domba kloning terbentuk. Selanjutnya embrio ditransfer ke rahim domba Blackface yang lain. Setelah masa gestasi, domba blackface melahirkan kembar (kloning) domba Finn Dorset, dengan sifatsifat yang identik dengan domba Finn Dorset pendonornya. ${ }^{15}$

Kloning manusia dilakukan dengan cara mengambil inti sel tubuh (nukleus) seseorang, lalu dimasukkan ke dalam sel telur wanita (setelah intinya dihilangkan/ dimandulkan). Lalu dengan bantuan cairan kimiawi khusus dan rangsangan arus listrik, inti sel digabungkan dengan sel telur. Setelah proses penggabungan terjadi, sel telur yang telah bercampur dengan inti sel itu diransfer ke dalam rahim seorang wanita, agar dapat memperbanyak diri, berkembang, berdiferensiasi dan tumbuh menjadi janin yang sempurna. Selanjutnya itu dilahirkan secara alami. ${ }^{16}$ Anak yang dilahirkan melalui proses reproduksi kloning memiliki kode genetika sama dengan kode genetik orang atau pemilik inti sel tubuh yang ditanamkan ke dalam sel telur wanita. Dalam kaitan ini, anak ahsil kloning tidak akan mewarisi gen (sifat menurun) dari wanita yang mengandungnya bila inti sel itu berasal dari luar (donor), baik donor laki-laki maupun wanita.

Realitas ini terwujud karena pembuahan dalam proses reproduksi kloning manusia terjadi pada sel-sel tubuh manusia, bukan pada sel-sel kelaminnya.. Memang dalam tubuh manusia terdapat miliaran bahkan triliunan sel. Dalam setiap sel tubuh manusia terdapat 46 kromosom (materi genetik yang mengandung sifat yang diturunkan pada manusia), kecuali sel-sel kelamin dalam testis laki-laki dan indung telur wanita, yang hanya mengandung 23 kromosom $^{17}$ atau separo dari jumlah kromosom pada sel-sel tubuh. Dalam

${ }^{15}$ Lihat Tim Fakultas Teknik UMJ Jakarta, Islam dan IPTEK, h. 167.

${ }^{16}$ Lihat Abdul Qadir Zullum, Kloning dan Permasalahannya, h. 18.

${ }^{17}$ Lihat Ahmad Baiquni, Al-Qur'an dan Ilmu Pengetahuan Kealaman (Cet. I; Jakarta: PT Dana Bhakti Prima Yasa, 1996), h. 189-190. 
hubungan ini, fungsi inti sel tubuh identik dengan fungsi sel sperma (laki-laki) yang dapat membuahi sel telur wanita (yang telah dikosongkan inti selnya atau dimandulkan).

Walaupun reproduksi manusia secara kloning hampir sama dengan bayi tabung, akan tetapi sebenarnya bayi tabung berbeda dengan kloning, antara lain: 1). Pada pembuahan alami dan inseminasi buatan (bayi tabung), sel sperma lakilaki yang mengandung 23 kromosom bertemu dengan sel telur wanita yang juga mengandung 23 kromosom. Pada saat terjadi ovulasi (pembuahan antara sel sperma dengan sel telur), maka jumlah kromosom embrio menjadi 46 kromosom. Sehingga anak yang dilahirkan akan memiliki ciri hereditas yang berasal dari kedua orang tuanya, baik laki-laki maupun wanita. Sedangkan dalam proses kloning manusia, inti sel tubuh seseorang itu mengandung 46 kromosom, sehingga anak hasil kloning hanya mempunyai kesamaan sifat dengan pemilik inti sel tubuh. Hal itu ibarat hasil foto copy selembar gambar pada mesin foto copy yang berwarna yang berupa selembar gambar aslinya tanpa ada perbedaan sedikit pun; dan, 2). Proses pembuahan alami dan inseminasi buatan (bayi tabung) membutuhkan adanya laki-laki dan wanita dengan adanya sel-sel kelamin, sedangkan proses kloning dapat berlangsung tanpa adanya laki-laki serta terjadi pada sel-sel tubuh, bukan sel-sel kelamin. Jelasnya, kloning manusia dapat terjadi meski dengan seorang wanita saja tanpa melibatkan laki-laki. ${ }^{18}$

Dengan demikian dapat dikatakan bahwa proses kloning telah menyingkap fakta bahwa pada sel tubuh manusia dan hewan terdapat potensi menghasilkan keturunan, apabila inti sel tubuh tersebut ditanamkan pada sel telur wanita yang telah dihilangkan inti selnya. Jadi, sifat inti sel tubuh tersebut laksana sperma laki-laki yang dapat membuahi sel telur wanita. Dihilangkannya inti sel telur (ovum) wanita dalam proses kloning berkaitan dengan prosedur ilmiah karena dalam sel telur itu terdapat 23 kromosom.

Kalau inti sel telur tidak dihilangkan, maka inti sel tubuh yang akan ditanamkan pada sel telur itu tidak akan terwujud, karena jika hal itu terjadi maka secara teoritis kromosom janin melalui proses kloningh itu akan berjumlah 69 buah (46 dari inti sel tubuh dan 23 buah dari sel telur). Padahal jumlah kromosom manusia hanya 46 buah. Karena itulah, inti sel telur harus dihilangkan.

\section{Kloning Perspektif Hukum Islam di Indonesia}

Hukum Islam Indonesia mencakup hukum Islam yang ada dalam fikih, Kompilasi Hukum Islam (KHI), Undang-Undang Perkawinan dan peraturan perundang-undangan lainnya yang memiliki spirit hukum Islam. Dalam artikel ini hukum Islam di Indonesia dibatasi pada hukum Islam produk fikih,

${ }^{18}$ Lihat Abdul Qadir Zullum, Kloning dan Permasalahannya, h. 25. 
Kompilasi Hukum Islam dan Undang-Undang Perkawinan serta Fatwa Majelis Ulama Indonesia.

Hukum Islam Indonesia merupakan semua aturan hukum yang mengikat dan bersifat memaksa semua umat Islam di Indonesia. Sifat mengikat dan memaksa dari aturan hukum Islam Indonesia kepada umat Islam di Indonesia tersebut bukan semata-mata adanya legislasi aturan hukum hukum Islam dalam bentuk peraturan perundang-undangan namun ditentukan pula oleh keyakinan. Krabe seperti dikutip Nur A. Fadhil Lubis, dengan mendasarkan pada doktrin rasa keadilan mengemukakan, bahwa tidak ada peraturan yang dapat mengikat manusia, kecuali dia menerimanya berdasarkan keyakinannya sendiri. ${ }^{19}$ Keyakinan umat Islam kepada Allah dengan sendirinya harus mentaati aturan hukum Islam yang diformulasi oleh para ulama dari Al-Qur'an dan hadis atau melalui dalil-dalil aqliyah. Sifat mengikat aturan hukum Islam tersebut akan semakin kuat jika aturan hukum Islam itu telah dilegislasi dalam peraturan perundang-undangan baik secara mandiri maupun secara integral.

Kompilasi Hukum Islam merujuk kitab-kitab fiqh (kitab kuning). Kitabkitab tersebut telah diteliti oleh para pakar dari 10 IAIN se-Indonesia saat itu, ${ }^{20}$ sehingga menurut eksistensi, Kompilasi Hukum Islam pada hakekatnya merupakan hukum Islam yang keberadaannya secara mandiri diakui berkekuatan hukum nasional dan sebagai hukum nasional di Indonesia. ${ }^{21}$ Kompilasi Hukum Islam pada satu sisi merupakan hukum Islam sebab bersumber langsung pada materi fiqh dan pada sisi lain Kompilasi Hukum Islam telah merupakan hukum nasional sebab telah diatur dalam Instruksi Presiden. Begitu juga Undang-Undang Perkawinan yang memuat aturan perkawinan yang sangat sesuai dengan hukum Islam. Hal senada diwujudkan dalam Fatwa Majelis Ulama Indonesia yang merespon berbagai permasalahan hukum Islam yang terjadi dalam masyarakat Indonesia pada umumnya mengacu pada sumber hukum Islam; al-Qur'an dan hadis serta dalil-dalil hukum Islam, dan pendapat ulama fiqh. Dengan demikian fatwa Majelis Ulama Indonesia merupakan produk hukum Islam di Indonesia.

Kloning tumbuhan dan hewan mempunyai manfaat baik terhadap perkembangan ilmu pengetahuan maupun kesejahteraan manusia. Dengan ditemukannya DNA unggul dan DNA cacat, dapat dikembangkan DNA dari pohon jati unggul untuk memperluas, mempercepat dan meningkatkan kualitas

${ }^{19}$ Lihat Nur A. Fadhil Lubis, "Penanggulangan Krisis dan Pemulihan Sistem Hukum di Indonesia: Analisa Sumbangan Hukum Islam," dalam Akhmad Mujahidin, et al., Aktualisasi Hukum Islam Tekstual dan Kontekstual (Cet. 1; Riau: PPS IAIN Suska, 2007), h. 170.

${ }^{20}$ Lihat Marzuki dan Rumadi, Figh Madzhab Negara Kritik Atas Politik Hukum Islam di Indonesia (Cet. 1; Yogyakarta: LKiS, 2001), h. 155-156.

${ }^{21}$ Lihat Ichtijanto S.A., "Pengadilan Agama Sebagai Wadah Perjuangan Mengisi Kemerdekaan Bangsa," dalam Departemen Agama RI, Kenang-Kenangan Seabad Pengadilan Agama (Cet. 1; Jakarta: Ditbinpera Depag RI, 1985), h. 263. 
reboisasi. Juga keberhasilan kloning domba, maka dapat dikembangkan produk domba atau hewan masa depan untuk memenuhi kebutuhan protein hewani manusia. ${ }^{22}$ Kloning juga dapat dimanfaatkan untuk penelitian di bidang medis untuk kebutuhan pengobatan.

Menurut penulis, bahwa secara keilmuan, keberadaan kloning manusia setidaknya menjadi penemuan baru sekaligus bukti rasional (walaupun tidak pasti) terhadap kelahiran Nabi Isa as yang tanpa ayah. Karena melalui proses kloning, dimungkinkan terbentuknya embrio hanya dengan adanya wanita tanpa peran laki-laki. Dalam hal ini inti sel tubuh yang telah dihilangkan inti selnya mampu membuahi sel telur (yang telah dimandulkan). Kejadian kelahiran Isa atau "kloning Isa adalah merupakan rekayasa Ilahi." ${ }^{23}$ Walaupun Nabi Isa as bukan hasil kloning dan tidak serta merta pula menjadi justifikasi kebolehan kloning manusia dalam hukum Islam. Jadi, kloning manusia pada satu sisi memberi manfaat terhadap perkembangan ilmu pengetahuan namun pada sisi lain menimbulkan problema bagi kemanusiaan. Segi manfaat yang dimaksudkan adalah dimungkinkannya teknologi kloning untuk menggandakan embrio dalam jutaan kali lipat. Hal ini dapat menjadi solusi untuk mengatasi kelangkaan jumlah penduduk akibat perang, atau bencana alam. Atau memenuhi keinginan untuk mendapatkan keturunan yang unggul baik dari fisik, intelektual, kekuatan maupun kesehatan.

Dalam kasus kloning manusia terjadi tarik ulur antara kepentingan ilmu ala Barat yang bebas nilai moral. Dalam kaitan ini, menurut Roger Graudy, bahwa manusia barat mengingkari transendensi Ilahi dan nilai-nilai mutlak dan menjadi "pertumbuhan" sebagai agama baru, yang menganggap pertumbuhan material sebagai nilai-nilai transenden dan tujuan peradaban. Yang berarti ia adalah sebuah peradaban tanpa tujuan-tujuan kemanusiaan dan moral. ${ }^{24}$ Peradaban yang sedemikian itu akan menimbulkan problem bagi manusia.

Jelasnya, kloning mengancam harkat martabat manusia atau moral. Dalam kaitan ini secara aksiologi, apakah kloning dapat mewujudkan kemaslahatan bagi umat manusia, sebagaimana tujuan penetapan syariat Islam (maqasid al-syari'ah)? Indikator yang dapat digunakan dalam kasus ini adalah lima unsur utama untuk memelihara kebutuhan-kebutuhan yang bersifat esensial bagi kehidupan manusia, yakni pemeliharaan agama, jiwa, harta, akal,

${ }^{22}$ Noeng Muhajir, Filsafat Ilmu Positivisme, Post Positivisme, dan Post Modernisme (Cet. 1; Yogyakarta: Rake Erasin, 2001), h. 272.

${ }^{23}$ Aziz Mushofa dan Imam Musbikin, Kloning Manusia Abad XXI, h. 72.

${ }^{24}$ Muhsin al-Mayliy, Rujih Gharudi wa al-Musykilat al-Diniyah, terj. Rifyal Ka'bah, Pergulatan Mencari Islam Perjalanan Religius Roger Graudy (Cet. 1; Jakarta: Paramadina, 1996), h. 227-228. 
dan keturunan. ${ }^{25}$ Kelima indikator tersebut merupakan manifestasi nilai keadilan dan moral tertinggi dalam Islam.

Proses "reproduksi" manusia melalui kloning dilihat dari aspek pemeliharaan agama, jiwa dan akal, tidak menimbulkan dampak negatif terhadap eksistensi agama dan jiwa karena justru melahirkan jiwa yang baru, begitu pula kloning manusia tidak mengancam eksistensi akal manusia bahkan dapat mencapai kesuksesan manusia dapat merekayasa kelahiran manusia yang jenius. Akan tetapi dilihat dari pemeliharaan keturunan (hifz al-nasl), kloning terhadap manusia perlu dipertanyakan. Karena proses kloning hanya mewarisi gen dari pemilik sel tubuh. Jika pemilik sel tubuh yang dimasukkan ke dalam sel telur itu berasal dari laki-laki yang terikat perkawinan yang sah (suami dari pemilik sel telur), maka menurut Islam anak yang dilahirkan itu adalah anak sah, namun secara genetika ia hanya mewarisi gen ayahnya. Apalagi jika sel tubuh berasal dari istri, maka secara genetika anak itu hanya mempunyai ibu tanpa ayah. Hal itu akan lebih parah lagi jika sel tubuh dan rahim berasal dari donor, maka anak yang dilahirkan dari proses kloning itu semakin tidak jelas nasabnya. Sebab rahim wanita yang menjadi tempat pemindahan sel telur yang telah dibuahi oleh inti sel donor hanya sekedar penampung saja.

Jelasnya, anak yang dilahirkan melalui proses kloning tidak mempunyai status nasab yang jelas. Padahal nasab seseorang sangat erat kaitannya dengan syariat Islam seperti perkawinan, waris, dan hubungan kemahraman. Jadi, kloning dapat mengaburkan bahkan menghilangkan status nasab, dan hal ini diancam oleh Rasulullah SAW dengan laknat Allah, sesuai sabdanya: "Barangsiapa yang menghubungkan nasab kepada yang bukan ayahnya atau (seorang budak) bertuan (taat) kepada selain tuannya, maka dia akan mendapat kutukan dari Allah, para malaikat dan seluruh manusia". ${ }^{26}$ (HR. Ibn Majah dari Ibn Abbas)

Bahkan suatu saat akan muncul image, bahwa institusi perkawinan, keluarga dan hubungan antara wanita dan laki-laki tidak dibutuhkan lagi sebab melalui kloning, manusia dapat dilahirkan melalui reproduksi di antara sesama wanita saja tanpa peran serta laki-laki. ${ }^{27}$ Sehingga dapat mengancam kesakralan sebuah perkawinan. Di samping itu kloning manusia menafikan keragaman yang akan menimbulkan problem dalam interaksi kehidupan sosial manusia, karena manusia-manusia yang dihasilkan melalui kloning memiliki sifatsifat fisik yang sama sehingga sulit dibedakan antara satu sama lain. Seorang suami sulit mengenali isterinya di antara wanita lain yang juga merupakan copian yang

${ }^{25}$ Lihat Muhammad Abu Zahrah, Usul a- Figh, terj. Saefullah Ma'sum dkk., Ushul Figh (Jakarta: Pustaka Firdaus, 1999), h. 548. Lihat pula M. Quraish Shihab, et al., Filsafat Hukum Islam (Cet. II; Jakarta: Bumi Aksara, 1992), h. 65-66.

${ }^{26 I b n}$ Majah, Sunan Ibn Majah, Juz II (Beirut: Dar al- Fikr, t.t.), h. 870.

${ }^{27}$ Ratna Megawangi, Membiarkan Berbeda? Sudut Pandang Baru tentang Relasi Gender (Cet. 1; Bandung: Mizan, 1999), h. 182. 
persis sama dengan ciri-ciri fisik isterinya. Penyidik juga akan sulit mengenali pelaku tindak pidana dari salah seorang dari saudara manusia kloning, sebab wajah mereka serupa, bentuk tubuh serupa dan sidik jarinya serupa. ${ }^{28}$ Dengan demikian kloning manusia secara sosiologis dan hukum akan menimbulkan problem dan dilema dalam kehidupan manusia.

Sebenarnya kloning berlangsung melalui sunnatullah, tetapi proses sunnatullah haruslah bersesuaian dengan moral syariat Allah. Artinya, manusia memiliki kebebasan merekayasa sunnatullah dalam alam raya ini, namun ia harus memperhatikan keselarasan antara rekayasanya dengan moral syariat. Karena syariat berkaitan dengan kemaslahatan hidup manusia. Jika hal itu tidak diindahkan maka kemampuan science dan teknologi manusia justru membawa manusia kepada keterpurukan dan kehancuran kemanusiaan.

Proses penciptaan manusia sebagaimana dijelaskan dalam al-Qur'an melalui sunnatullah. Begitu pula proses kloning manusia adalah proses "penciptaan" manusia melalui sunnatullah dengan keikutsertaan manusia dalam merekayasa sebagian proses sunnatullah tersebut. Sunnatullah itu dapat diketahui dan direkayasa dengan kemajuan ilmu pengetahuan manusia, karena sunnatullah sendiri merupakan suatu ketetapan yang tidak berubah (exact). Karena kepastiannya dan kemapanan sunnatullah itu sehingga manusia dapat membuat formulasinya dan merekayasanya dengan metode yang lain setelah mempelajari substansi zat yang berperan dalam proses reproduksi manusia. Sifat eksak sunnatullah itu telah diisyaratkan dalam QS. Al-Fath (48): 23 yaitu "Sebagai suatu sunnatullah yang telah berlaku sejak dahulu, kamu sekali-kali tiada akan menemukan peubahan bagi sunnatullah itu".

Berdasarkan uraian di atas, dapat dikemukakan bahwa kloning bukan semata-mata didasarkan kepada ketidaksamaan proses reproduksi manusia secara alami dengan proses kloning manusia. Akan tetapi lebih difokuskan pada fenomena yang melekat pada manusia hasil kloning tersebut. Kesuksesan teknologi kloning manusia tidak identik dengan legitimasi syariat Islam terhadap kloning manusia. Keharmonisan kehidupan manusia itu dapat terwujud jika kemampuan intelektual sains sejalan dengan spiritual sains. Tidak ada batas ketinggian dan kedalaman kemampuan penemuan sains manusia, namun manusia dibatasi oleh moral syariat. Setinggi apa pun kemampuan manusia tidak akan menemukan keselarasan dan keharmonisan hidup jika ia tidak sejalan dengan traffic lights syariat Allah, yang bersumber pada tauhid dan bermuara pada rida Allah.

Dengan demikian Islam menolak anggapan bahwa agama dan sains pada tingkat tertentu berjalan tidak paralel, sehingga muncul pemikiran yang mengisyaratkan adanya dikhotomi antara ilmu pengetahuan agama dan sains.

${ }^{28}$ Yusuf Qardawi, Hady al-Islam Fatawi Mu'asirah, terj. Samson Rahman, dkk., Fatwa-Fatwa Kontemporer, Jilid 3 (Cet. 1; Jakarta: Pustaka Al-Kautsar, 2002), h. 515. 
Menurut Islam, IPTEK tidak bebas nilai bahkan sarat dengan nilai, antara lain nilai ekonomi dalam pengertian, bahwa dalam IPTEK terkadang usaha dari para penemu/pengembangnya untuk mendapatkan nilai tambah yang bisa menimbulkan keuntungan ekonomi. ${ }^{29}$ Kalau pengetahuan itu terus berjalan tanpa memperhatikan rambu-rambu moral syariat, maka kemajuan ilmu pengetahuan tersebut justru akan membawa keruntuhan martabat manusia. Dengan demikian, meskipun kloning manusia sesuai dengan sunnatullah tetapi tidak sejalan dengan moral syariat Islam.

Berdasarkan uraian di atas dari perspektif fikih, anak yang dihasilkan melalui teknologi kloning dengan penggunaan sel tubuh suami dan ovum istri serta embrionya ditransfer ke dalam rahim istri pemilik ovum, pada satu sisi tampak mirip dengan anak yang dihasilkan teknologi bayi tabung dari sel sperma suami, dan ovum istri serta dikembangkan dalam rahim istri sendiri. Bayi tabung memang dibolehkan didasarkan pada pertimbangan tingkat kebutuhan (hajiyat) yang besar pasangan suami istri terhadap anak sebagai penerus keturunannya. Hajat tersebut dapat meningkat ke derajat kebutuhan daruriyat, sesuai dengan kaidah fiqh bahwa: "Hajat (kebutuhan yang sangat penting itu) diperlakukan seperti dalam keadaan terpaksa (emergency) padahal keadaan darurat/terpaksa membolehkan melakukan hal-hal yang terlarang" ${ }^{30}$

Perwujudan kebutuhan pasangan suami istri terhadap anak yang menjadi pelanjut keturunan mereka pada satu sisi sangatlah urgen. Namun pada sisi lain anak yang dihasilkan melalui kloning masih dikhawatirkan kejelasan nasabnya, padahal salah satu maqasid al-syari'ah, adalah menjaga kemurnian keturunan (hifz al-nasl). Kerancuan nasab anak kloning terjadi, sebab penggunaan sel tubuh ayah dan ovum serta rahim istri sendiri, meskipun bisa menghasilkan kehamilan pada istri, akan tetapi anak yang dilahirkan istri secara genetik hanya mewarisi ciri-ciri fisik ayahnya saja tanpa mewarisi ciri-ciri fisik ibunya sama sekali. Begitu juga sebaliknya, jika sel tubuh, ovum dan Rahim dari istri, maka anaknya hanya mewarisi ciri fisik yang sama dengan ciri fisik ibunya saja.

Hal itu dapat menimbulkan problem dalam perspektif hukum Islam di Indonesia yang diatur Undang-Undang Perkawinan. Menurut pasal 42 UndangUndang Nomor 1 Tahun 1974 Tentang Perkawinan, bahwa "Anak yang sah adalah anak yang dilahirkan dalam atau sebagai akibat perkawinan yang sah." 31 Ayat 42 Undang-Undang Perkawinan ini menunjukkan, bahwa anak yang lahir dalam ikatan perkawinan sah tergolong anak sah. Anak sah yang dilahirkan dalam perkawinan yang sah adalah anak yang merupakan hasil reproduksi alami atau rekayasa reproduksi melalui bayi tabung setelah dilaksanakan

${ }^{29}$ Chairil Anwar, Islam dan Tantangan Kemanusiaan Abad XXI (Cet. 1; Yogyakarta: Pustaka Pelajar, 2000), h. 14-15.

${ }^{30}$ Masjfuk Zuhdi, Masail Fighiyah,(Cet. 10; Jakarta: Toko Gunung Agung, 1997), h. 21-22.

${ }^{31}$ Republik Indonesia, Undang-Undang RI Nomor 1 Tahun 1974 Tentang Perkawinan, pasal 42. 
perkawinan. Sedangkan anak sah yang dilahirkan akibat perkawinan yang sah, adalah anak yang berasal dari reproduksi yang terjadi sebelum perkawinan namun lahir setelah ayah ibunya melangsungkan perkawinan. Dengan demikian sepintas menurut Undang-Undang Perkawinan, bahwa anak hasil kloning yang berasal dari sel tubuh istri, ovum istri yang dikembangkan dalam rahim istri dikategorikan sebagai anak sah sama dengan anak hasil kloning yang berasal dari sel tubuh suami dan ovum istri yang dikembangkan dalam rahim istri sendiri. Akan tetapi jika ditelusuri sejarah perancangan Undang-Undang Perkawinan tersebut, maka dapat diketahui bahwa Undang-undang ini belum menyinggung penggunaan inseminasi buatan, baik bayi tabung maupun kloning manusia.

Keberadaan anak sah yang dihasilkan reproduksi buatan itu diisyaratkan dalam pasal 99 Kompilasi Hukum Islam (KHI), bahwa "anak yang sah" adalah: a). anak yang dilahirkan dalam atau akibat perkawinan yang sah; dan, b). hasil perbuatan suami istri yang sah diluar rahim dan dilahirkan oleh istri tersebut. ${ }^{32}$

Jika dikaitkan sejarah penyusunan Kompilasi Hukum Islam, maka pembuahan buatan yang terjadi di luar Rahim yang dimaksudkan KHI di atas adalah bayi tabung. Meskipun proses pembuahan dalam bayi tabung terjadi di luar rahim, namun proses pertumbuhan dan perkembangan janin berlangsung dalam rahim. Dengan demikian yang menjadi standar dalam penentuan hukumnya adalah sumber sperma harus dari suami, ovum dan Rahim dari istri. Ketiga unsur inilah yang menjadi esensi penentu legalitas anak yang dihasilkan melalui bayi tabung. Sedangkan anak yang dihasilkan teknologi kloning mendayagunakan potensi sel tubuh (bukan sel kelamin) yang dihilangkan inti selnya untuk membuahi sel telur yang dikosongkan inti selnya, lalu embrionya ditransfer ke dalam rahim. Karena itu pula meskipun sepintas Undang-Undang Perkawinan dan Kompilasi Hukum Islam (KHI) mengisyaratkan pengakuan anak kloning dari sel tubuh suami, ovum dan rahim istri sebagai anak sah, namun tidak adanya sifat menurun dari ibu kepada anak akan menimbulkan kerancuan nasab serta berbagai problem lain dalam kehidupan anak hasil kloning.

Berdasarkan uraian di atas, dapat diungkapkan bahwa teknologi kloning manusia berpotensi menimbulkan dampak negatif, di antaranya pengabaian institusi perkawinan di kalangan perempuan. Sebab perempuan yang tak mau terikat perkawinan bisa mewujudkan impiannya memiliki anak melalui kloning dengan menggunakan sel tubuh, ovum dan rahimnya sendiri. Hal itu akan berbeda dengan laki-laki sebab laki-laki meskipun bisa menggunakan sel tubuhnya, namun masih membutuhkan ovum dan rahim seorang istri. Dengan demikian kloning terhadap manusia di samping memiliki manfaat, juga

${ }^{32}$ Departemen Agama RI, Kompilasi Hukum Islam (Jakarta: Direktorat Pembinaan Peradilan Agama Islam Depag, 2001). 
mengandung bahaya. Dalam kaitan ini Majelis Ulama Indonesia (MUI) mengemukakan bahwa kloning terhadap manusia dapat menimbulkan mafsadat (bahaya) antara lain: a) menghilangkan nasab anak hasil kloning yang berakibat hilangnya banyak hak anak dan terabaikannya sejumlah hukum yang timbul dari nasab; b) insitusi perkawinan yang telah disyariatkan sebagai berketurunan secara sah menjadi tidak diperlukan lagi, sebab proses reproduksi dapat dilakukan tanpa melakukan hubungan seksual; c) lembaga keluarga (yang dibangun melalui perkawinan) akan menjadi hancur, dan pada gilirannya akan terjadi pula kehancuran moral (akhlak), budaya, hukum, dan syariah Islam lainnya; d) tidak aka nada lagi saling mencintai dan saling membutuhkan antara laki-laki dan perempuan; dan, e) hilangnya maqasid al-syari'ah dari perkawinan, baik maqasid awwaliyah (utama) maupun maqasid tabi'ah (sekunder).

Sebab itu Musyawarah Nasional VI Majelis Ulama Indonesia (MUI) mengeluarkan fatwa Nomor 3/MUNAS VI/MUI/2000 tentang Kloning mengeluarkan fatwa bahwa: 1). Kloning terhadap manusia dengan cara bagaimana pun yang berakibat pada pelipatgandaan manusia hukumnya adalah haram; 2). Kloning terhadap tumbuh-tumbuhan dan hewan hukumnya boleh (mubah) sepanjang dilakukan demi kemaslahatan dan/atau untuk menghindarkan kemudaratan (hal-hal negatif); dan, 3). Mewajibkan kepada semua pihak terkait untuk tidak melakukan atau mengizinkan eksperimen atau praktek kloning terhadap manusia. ${ }^{33}$

Mencermati fatwa Majelis Ulama Indonesia (MUI) dapat dikemukakan bahwa meskipun sel tubuh dari suami dan ovum serta Rahim istri sendiri syubhat hukumnya. Sebab hilangnya gen dari ibu akan menimbulkan problem psikologis, sosial dan hukum juga di kemudian hari. Sesuatu yang syubhat lebih dekat kepada haram.

Fatwa Majelis Ulama Indonesia (MUI) tentang kloning itu didasarkan pada QS. al-Isra (17): 70 yaitu, "Dan Sesungguhnya telah Kami muliakan anakanak Adam, Kami angkut mereka di daratan dan di lautan, Kami beri mereka rezki dari yang baik-baik dan Kami lebihkan mereka dengan kelebihan yang sempurna atas kebanyakan makhluk yang telah Kami ciptakan."

Ayat ini mengungkapkan pernyataan Allah yang telah memuliakan manusia. Sedangkan kloning manusia pada hakekatnya merupakan bentuk pelecehan terhadap harkat dan martabat manusia. Semua tindakan yang merendahkan harkat dan martabat manusia adalah haram dilakukan.

Di samping itu MUI juga mendasarkan fatwanya pada QS. al-Mu'minun (23): 12-14 yaitu, "Dan sesungguhnya Kami telah menciptakan manusia dari suatu saripati (berasal) dari tanah. Kemudian Kami jadikan saripati itu air mani

33Departemen Agama RI, Himpunan Fatwa Majelis Ulama Indonesia (Jakarta: Bagian Proyek Sarana dan Prasarana Produk Halal Depag, 2003), h. 346-348. 
(yang disimpan) dalam tempat yang kokoh (rahim). Kemudian air mani itu Kami jadikan segumpal darah, lalu segumpal darah itu Kami jadikan segumpal daging, dan segumpal daging itu Kami jadikan tulang belulang, lalu tulang belulang itu Kami bungkus dengan daging. kemudian Kami jadikan Dia makhluk yang (berbentuk) lain. Maka Maha sucilah Allah, Pencipta yang paling baik".

Ayat ini mengisyaratkan, bahwa reproduksi manusia melibatkan peran serta laki-laki (suami) yang memberikan kontribusi sperma, dan perempuan (istri) yang memberikan kontiribusi ovum dan rahim dalam ikatan perkawinan. Peran serta kedua insan tersebut dapat terabaikan baik salah satunya maupun kedua-duanya dalam kloning manusia. Dengan demikian unsur mafsadat (dampak negatif) kloning manusia lebih besar daripada unsur manfaatnya, sehingga kloning manusia harus dilarang, sesuai kaidah fiqh yang digunakan dalam Fatwa MUI di atas yakni: "Menghindarkan kerusakan (hal-hal negatif) diutamakan dari pada mendatangkan kemaslahatan". ${ }^{34}$

Menurut penulis, meskipun kloning manusia dapat mewujudkan keturunan yang menjadi tujuan perkawinan, namun mudaratnya tampaknya lebih luas dari pada manfaatnya. Jika dicermati, mudarat dari mendapatkan anak melalui kloning lebih besar dari manfaatnya. Maslahat (manafaat)nya adalah mendapatkan anak kandung namun mudaratnya jauh lebih luas, di antaranya nasab anak menjadi tidak jelas yang berimplikasi negatif pada perkawinan, perwalian, kewarisan, tanggungjawab orangtua kepada anak dan sebaliknya. Bahkan akan menyulitkan dalam penegakan hukum pidana.

\section{Kesimpulan}

Berdasarkan pembahasan sebelumnya dapat disimpulkan bahwa kloning merupakan teknologi reproduksi makhluk hidup secara aseksual. Dalam hal ini reproduksi manusia secara kloning, mendayagunakan potensi sel tubuh manusia yang setelah dihilangkan inti selnya ternyata berpotensi seperti sperma, mampu membuahi sel telur wanita yang telah dimandulkan. Kesuksesan kloning pada hewan, tumbuhan dan manusia pada dasarnya telah sesuai dengan sunnatullah, namun demikian tidak menjadi justifikasi hukum Islam terhadap kloning manusia.

Secara hukum, kloning manusia pada satu sisi memiliki manfaat untuk manusia. Dari sudut ilmu pengetahuan, kloning manusia dapat menunjang perkembangan dan kemajuan ilmu pengetahuan. Begitu pula dari segi akidah, tidak melanggar 'wilayah kodrati Ilahi. Tetapi pada sisi hukum dan moral, kloning manusia mengancam harkat martabat manusia, karena anak yang

${ }^{34}$ Departemen Agama RI, Himpunan Fatwa Majelis Ulama Indonesia (Jakarta: Bagian Proyek Sarana dan Prasarana Produk Halal Depag, 2003), h. 348. 
dilahirkan walaupun berasal dari sel tubuh ayah, ovum dan rahim ibunya, namun sifat genetik anak hanya berasal dan serupa dengan ayahnya dan tidak memiliki sifat genetik dengan ibunya sehingga memiliki dampak negatif secara sosial, psikologis, dan hukum. Anak-anak hasil kloning memiliki ciri fisik yang sama sehingga menimbulkan problem dalam penyelidikan, penyidikan pelaku perkara pidana. Begitu juga akan membingungkan dalam tatanan hubungan antara suami dengan ipar perempuan atau istri dengan ipar laki-laki lantaran iparnya memiliki ciri fisik yang sama dengan suami atau istrinya. Apalagi jika sel tubuh, ovum dan rahim dari ibu si anak kloning maka ciri fisik dan nasab hanya dengan ibu saja. Hal itu akan berdampak buruk dalam nasab, perkawinan, kewarisan, perwalian, dan tanggungjawab ayah kepada anak atau sebaliknya. Apalagi pemeliharaan nasab (hifz al-nasl) memiliki posisi yang sangat penting dalam hukum Islam. Karena itu hukum Islam di Indonesia melarang kloning manusia, baik yang diatur dalam fiqh maupun fatwa Majelis Ulama Indonesia. Meskipun dalam Undang-Undang Perkawinan dan Kompilasi Hukum Islam (KHI) mengakui anak yang lahir dalam atau akibat dari perkawinan sebagai anak sah, serta anak yang dihasilkan di luar pembuahan alami, namun UndangUndang Perkawinan dan Kompilasi Hukum Islam belum menyinggung anak hasil kloning, sebab kloning manusia belum ada pada saat RUU Perkawinan digodok, dan KHI dirancang.

\section{Pustaka Acuan}

Abu Zahrah, Muhammad. Usul al-Figh. Terj. Saefullah Ma'sum dkk., Ushul Fiqh. Jakarta: Pustaka Firdaus, 1999.

Aji, Ahmad Mukri. Kontekstualisasi Ijtihad Dalam Diskursus Pemikiran Hukum Islam di Indonesia, Bogor: Pustaka Pena Ilahi, 2010.

Aji, Ahmad Mukri. Urgensi Maslahat Mursalah Dalam Dialektika Pemikiran Hukum Islam, Bogor: Pustaka Pena Ilahi, 2012.

al-Mayliy, Muhsin. Rujih Gharudi wa al-Musykilat al-Diniyah. Terj. Rifyal Ka'bah, Pergulatan Mencari Islam Perjalanan Religius Roger Graudy. Cet. 1; Jakarta: Paramadina, 1996.

Anees, Munawar Ahmad. Islam and Biological Futures: Ethics, Gender and Technology. Terj. Rahmani Astuti, Masa Depan Biologis Umat Manusia: Etika Gender dan Teknologi, Cet. 1; Bandung: Mizan, 1993.

Anwar, Chairil. Islam dan Tantangan Kemanusiaan Abad XXI, Cet. 1; Yogyakarta: Pustaka Pelajar, 2000.

Azhary, Muhammad Tahir. Negara Hukum Suatu Studi tentang Prinsip-Prinsipnya Dilihat dari Segi Hukum Islam, Implementasinya pada Periode Negara Madinah dan Masa Kini, Edisi kedua, Cet. 2; Jakarta: Prenada media, 2004. 
Badudu, J.S dan Sutan Muhammad Zain, Kamus Besar Bahasa Indonesia, Cet. 1; Jakarta: Pustaka Sinar Harapan, 1994.

Baiquni, Ahmad. Al- Qur'an dan Ilmu Pengetahuan Kealaman, Cet. 1; Jakarta: PT Dana Bhakti Prima Yasa, 1996.

Bakry, M. Nurchalis dkk. Bioteknologi dan Al-Qur'an, Cet. 2; Jakarta: Gema Insani Press, 1996.

Cole, Barbara Letta, et al. Encyclopedia Americana, Vol. 7. Danbura: Grolier Incorporated, 1993.

Departemen Agama RI. Himpunan Fatwa Majelis Ulama Indonesia, Jakarta: Bagian Proyek Sarana dan Prasarana Produk Halal Depag, 2003.

Departemen Agama RI. Kompilasi Hukum Islam, Jakarta: Direktorat Pembinaan Peradilan Agama Islam Depag, 2001.

Ibn Majah. Sunan Ibn Majah, Juz II, Beirut: Dar al- Fikr, t.t.

Krishnayanti, Ika N. Bioteknologi dan Keselamatan Hayati, Jakarta: Konpalindo, 1995.

Lubis, Nur A. Fadhil. "Penanggulangan Krisis dan Pemulihan Sistem Hukum di Indonesia: Analisa Sumbangan Hukum Islam." Dalam Akhmad Mujahidin, et al., Aktualisasi Hukum Islam Tekstual dan Kontekstual, Cet. 1; Riau: PPS IAIN Suska, 2007

Maggalatung, A Salman. "Hubungan Antara Fakta Norma, Moral, Dan Doktrin Hukum Dalam Pertimbangan Putusan Hakim," dalam Jurnal Cita Hukum, Vol. 2, No. 2 (2014).

Marzuki dan Rumadi, Figh Madzhab Negara Kritik Atas Politik Hukum Islam di Indonesia,Cet. 1; Yogyakarta: LKiS, 2001

Megawangi, Ratna. Membiarkan Berbeda? Sudut Pandang Baru Tentang Relasi Gender, Cet. 1; Bandung: Mizan, 1999.

Muhajir, Noeng. Filsafat Ilmu Positivisme, Post Positivisme, dan Post Modernisme, Cet. 1; Yogyakarta: Rake Serasin, 2001.

Qardawi, Yusuf. Hady al-Islam Fatawi Mu'asirah. Terj. Samson Rahman, dkk., Fatwa-Fatwa Kontemporer, Jilid 3, Cet. 1; Jakarta: Pustaka Al-Kautsar, 2002

Reksoatmojo, S.M. Issoegianti. Biologi Sel, Cet. 1; Jakarta: Depdikbud, 1994.

Republik Indonesia, Undang-Undang RI Nomor 1 Tahun 1974 Tentang Perkawinan.

S.A, Ichtijanto. "Pengadilan Agama Sebagai Wadah Perjuangan Mengisi Kemerdekaan Bangsa." Dalam Departemen Agama RI, Kenang-Kenangan Seabad Pengadilan Agama, Cet. 1; Jakarta: Ditbinpera Depag RI, 1985.

Shihab, M. Quraish et al. Filsafat Hukum Islam, Cet. 2; Jakarta: Bumi Aksara, 1992. 
Sofoewan, Sulchan. "Perkembangan IPTEKDOK Dalam Rekayasa Reproduksi." Dalam Muhammad Azhar dan Hamim Ilyas. Pengembangan Pemikiran Keislaman Muhammadiyah: Purifikasi dan Dinamisasi, Cet. 1; Yogyakarta: LPPI UMY, 2000.

Tim Fakultas Teknik UMJ Jakarta. Islam dan IPTEK, Buku Kedua, Cet. 1; Jakarta: PT Raja Grafindo Persada, 1998.

Wignjosoebroto, Soetandyo. "Kloning: Kemungkinan Teknis dan Implikasi Permasalahan Sosial-Etisnya." Dalam Aziz Mushofa dan Imam Musbikin, Kloning Manusia Abad XXI: Antara Harapan, Tantangan dan Pertentangan, Cet. 1; Yogyakarta: Forum Studi HIMANDA dan Pustakan Pelajar, 2001.

Yunus, Nur Rohim. Restorasi Budaya Hukum Masyarakat Indonesia, Bogor: Jurisprudence Press, 2012.

Zuhdi, Masjfuk. Masail Fiqhiyah, Cet. 10; Jakarta: Toko Gunung Agung, 1997.

Zullum, Abdul Qadir. Kloning dan Permasalahannya, Bandung: Mizan, 1997. 